explorers in the Andes have been recognised by the authors also in the Himalayan region, though their conclusions have not been completely accepted by other travellers. They, however, bring together in this work observations made in the Nun Kun area during 1906 , as well as others made before and since in other parts of the north-west Himalaya, and have a right, consequently, to generalise on the phenomena. The prominences grouped under the name nieve penitente are often roughty pyramidal in shape, and generally disposed in rows on snow and ice at altitudes at which the night temperature falls below the freezing point; they are due to the unequal melting of the superficial layers of snow and ice. The authors describe in detail eight varieties of nieves penitentes, which, judging by the descriptions given, might have been divided into the following two groups:-(i.) Those that are the outward and visible expression of an internal heterogeneity of physical structure induced in the snow and ice by (I) the scoring action of avalanches with a trend parallel to the dip-slope; (2) the shearing effects of slower subsidence along the slopes; (3) the development of pressure waves by the wind; and (4) the more or less regular fracturing on seracs. (ii.) Those that are due to the disposition of various adventitious covers, such as (5) thin patches of earthy material arranged by the wind, and of a kind facilitating the absorption of the sun's heat with consequent melting of the subjacent ice; (6) heavy rock-masses, which compress and protect the ice, giving rise, by melting of the clean ice around, to the well-known glacial tables; (7) thick layers of earthy material, having a protective effect similar to that of the large rock fragments, but giving rise to differently shaped prominences on account of the disintegration and fall of the marginal parts of the covers; $(8)$ water-covers in depressed areas, where silt is deposited unequally or a previously sculptured surface. These phenomena have been discussed in greater detail by Dr. Workman in special papers published in the Zeitschrift für Gletscherkunde and in the Altine Journal.

A notice of this book would not be complete without reference to the remarkably fine photographic plates with which it is illustrated, although the illustrations, specially selected to demonstrate the phenomena of nieve penitente, and perhaps the best in the book, are taken from other areas, mainly from the Hispar and associated glaciers, further north-west, in the chiefship of Nagar. One of these is here reproduced.

T. H. HOLLAND.

\section{THE EAST AFRICAN NATURAL HISTORY} SOCIETY.

THERE has been founded in British East Africa a society for the study of natural history, and the activities of this society naturally extend to the adjoining Lganda Protectorate. This society recently produced the first number of a Journal, which, it is to be hoped, may run to many volumes if conducted on the lines of its first number. Mr. C. W. Hobley, C.M.G., a prominent official of British East Africa, whose service there dates from the earliest days of the British East Africa Chartered Company, has taken a considerable part in the founding of this local natural history society, and is one of the contributors to the first number of the Journal. Mr. Hobley's work in anthropology, in East African languages, in geology, in the exploration of the aquatic fauna of Lake Victoria Nyanza (it will be remembered that he was the first, or one of the first,

1 The Journal of the Fast Africa and Cgnada Natural History Society. vol. i., No. 1, January, igra (London: Iongmans, Green and Co., 19ro.) Price 56 . net. to discover in that lake organismis akin to the supposed marine fauna of Lake Tanganyika, thereby lessening the acuteness of that problem), has been so remarkable that his association with the Natural History Society should be productive of interesting results.

This first number contains a very well-executed coloured illustration of a new species of francolin (Francolinus hubbardi). This accompanies an article on the francolins of East Africa and Uganda, which to ornithologists is of real value. The scope of this article also includes the allied genus Pternistes. Mr. Battiscombe gives some new and interesting information regarding the flora of British East Africa. There are several small errors in the nomenclature of this article; Lobelia johnstoni is given as Lobelia johnsonii; Kniphofia thomsoni appears as $K$. thompsonii, and Musa livingstonii is given as $M$. livingstonia. The generic name Sanseviera is misspelt-a very common fault in books dealing with Africa. But these are trifling defects in an account of East African botany which is of considerable interest.

The Rev. K. St. A. Rogers writes on East African butterflies. There are notes on the haunts and habits of the elephant on the Guas' Ngishu plateau by Mr. Hoey, and Mr. C. W. Hobley contributes two articles, the more important of which, from the point of view of new information, is that dealing with the Karianduss deposits of the Rift Valley-deposits which form beds of a mealy, friable rock, amounting perhaps to millions of tons of diatomite. This is a siliceous deposit, principally of organic origin, mainly composed of the skeletons of minute, lowly plants-diatoms or bacillaria-mere cells of green or brown protoplasm originally, which enclose themselves in a flinty casing titting together like a box and a lid. Diatoms are, of course, found in fresh-water ponds and salt seas all over the world. Mr. Hobley considers the Rift Valley to have been the scene of tremendous volcanic activity from Tertiary times onwards, and that at one period in its history this enormously long depression in the surface of East Africa was covered by much larger lakes than at the present day. These beds of diatomite are the result both of the existence of these sheets of water and of the neighbouring eruptive volcanoes.

" Picture Susiva, Longenot, and Eburu all periodically in active eruption, and in addition to lava flows ejecting great clouds of volcanic dust and streams of mud mainly composed of siliceous fragments. This is almost certain to have been thus, as is the case in all volcanoes of this kind: the steam tearing its way through the magma which formed the flows of obsidian and trachytic tuffs would naturally blow large quantities into a state of very fine division, and this would be spread far and wide by the wind and also carried into the lakes by the torrential downpours which always accompany volcanic activity. The soda-laden water would dissolve the silica and place it ready for the diatoms to work upon, and with such rich material to build with one can quite see that this form of life could flourish with great luxuriance."

Mr. Hobley considers this diatomite or kieselguhr may be of some economic value. H. H. Johnston.

\section{NOTES.}

Tue Astley Cooper prize for 19 ro has been awarded to Ptof. E. H. Starling, F.R.S., for an essay upon the physiology of digestion, gastric and intestinal.

THe Mackinnon studentship in physical sciences has been awarded by the Roval Society for a second year to Dr. R. D. Kleeman for the continuation of his researches on radio-activity; and the studentship in biological sciences has been awarded to Mr. 'T. Goodey for an investigation of the protozoa of the soil. 